\title{
Performance Analysis Of Civil Servants At The Department Of Education, Youth And Sport, Mamuju Regency, West Sulawesi
}

\author{
Muhtar ${ }^{1)}$, Andi Agustang 2) \\ 1) Department of Educational Administration, Postgraduate Program, Universitas Negeri Makassar, \\ Indonesia \\ 2) Universitas Negeri Makassar, Indonesia \\ Corresponding Author: Muhtar,Email: mudomuhtar7284@gmail.com
}

\begin{abstract}
History: Received 31/12/2021 | Revised 03/01/2022 | Accepted 18/01/2022 | Published 31/01/2022 Abstract. This study aims to describe: (1) the performance of civil servants Office of Education Youth and Sports Department (Dikpora) in terms of managerial ability, the ability of responsiveness, accountability, and discipline of civil servants work, and (2) the factors others that affect the performance of civil servants of Education Youth and Sports Department Mamuju Service office. The research method used is the survey method. The population of this study is all civil servants of Education Youth, and Sports Department Mamuju serves as the research sample of 42 people. To obtain data about managerial ability, the ability of responsiveness, accountability, and employee discipline obtained by using questionnaires and supported by interviews and observations, while data on other factors that affect the performance of civil servants is obtained by using the interview guide. The questionnaire used previously been tested and declared valid and reliable. The validity test with $\mathrm{N}=27$ and 0.05 confidence level obtained a value of r-table 0.381 . In the test reliability coefficient of 0.948 was obtained. All the data obtained using the questionnaire were analyzed using quantitative descriptive statistics, while data obtained by interview as described by descriptive qualitative research supporting data. Results showed that (1) managerial skills of civil servants by 57.14 percent in the medium category, (2) the ability of the responsiveness of 59.53 percent in the medium category, (3) accountability of 69.05 in the high category, (4) work discipline of 66.67 percent in the medium category, and (5) the performance of civil servants by 54.76 percent in the medium category. As for other factors that affect the performance of civil servants: (1) is a factor that supports the civil service work experience, skill factors, and education level employees, (2) that inhibits the factor of employee work culture.
\end{abstract}

Keywords: Performance, Managerial, Responsiveness, Accountability, Work Discipline

\begin{abstract}
Abstrak. Penelitian ini bertujuan memberikan gambaran mengenai: (1) kinerja pegawai negeri sipil (PNS) kantor Dinas Pendidikan Pemuda dan Olahraga (Dikpora) ditinjau dari kemampuan manajerial, kemampuan responsivitas, akuntabilitas, dan disiplin kerja PNS, serta (2) faktor-faktor lain yang mempengaruhi kinerja PNS kantor Dinas Dikpora Kabupaten Mamuju. Metode penelitian yang digunakan adalah metode survei sedangkan populasi penelitian ini adalah seluruh PNS Dinas Dikpora Kabupaten Mamuju dijadikan sebagai sampel penelitian yaitu 42 orang. Untuk memperoleh data mengenai kemampuan manajerial, kemampuan responsivitas, akuntabilitas, dan disiplin kerja pegawai diperoleh dengan menggunakan kuesioner dan didukung dengan wawancara dan observasi, sedangkan data mengenai faktor-faktor lain yang mempengaruhi kinerja PNS diperoleh dengan menggunakan pedoman wawancara. Kuesioner yang digunakan sebelumnya telah diuji cobakan dan dinyatakan valid dan reliabel. Pada uji validitas dengan $\mathrm{N}=27$ dan taraf kepercayaan 0,05 didapat nilai r-tabel 0,381. Pada uji reliabilitas didapat koefisien sebesar 0,948. Seluruh data yang diperoleh dengan menggunakan kuesioner dianalisis dengan menggunakan statistik deskriptif kuantitaif, sedangkan data yang diperoleh dengan wawancara diuraikan dengan deskriptif kualitatif sebagai data pendukung penelitian.Hasil penelitian menunjukkan bahwa (1) kemampuan manajerial PNS sebesar 57,14 persen dalam kategori sedang, (2) kemampuan responsivitas sebesar 59,53 persen dalam kategori sedang, (3) akuntabilitas sebesar 69,05 dalam kategori tinggi, (4) disiplin kerja sebesar 66,67 persen dalam kategori sedang, dan (5) kinerja PNS sebesar 54,76 persen dalam kategori sedang. Adapun faktor-faktor lain yang mempengaruhi kinerja PNS: (1) yang mendukung adalah faktor pengalaman kerja PNS, faktor kecakapan, dan tingkat pendidikan pegawai, (2) yang menghambat adalah faktor budaya kerja pegawai.
\end{abstract}

Kata kunci: Kinerja, Manajerial, Responsivitas, Akuntabilitas, Disiplin Kerja 


\section{INTRODUCTION}

The employee performance and improving the quality of education continue to be processed at the Dikpora Office of Mamuju Regency, especially after the enactment of Law Number 23 of 2014 concerning regional government and Law Number 20 of 2003 concerning National Education System Article 11 paragraph 1 that the Government and regional governments are obliged to provide services and convenience, as well as ensuring the implementation of quality education for every citizen without discrimination. (Masinambow \& Adolfina, 2017) Civil servants undoubtedly provide services to the community in a professional, honest, fair, and equitable manner in carrying out state, government and development tasks.

The Dikpora Office, in carrying out its duties to achieve its vision, must be supported by good management and qualified human resources from the leadership to the staff. (Terry, 2008) explains that an organization will achieve its goals if the management is supported by leadership capabilities and technical capabilities by the people who are invited to work together. The leadership's ability and the staff's technical ability are the benchmarks for HR performance.

According to (Retno Sulistiyo, 2019), Civil Servant (PNS) performance is the result of work measured based on predetermined performance indicators, including work quality, accuracy, initiative, ability, and communication. (Robins, 2001) defines performance as a synergy of several elements: ability, motivation, and opportunity. The success of the employee's performance is highly dependent on the work performance of his HR, and therefore, the results of the work performed must be able to pass the indicators that have been set. The ability factor is the essential ability for staff and an advanced ability for a manager in carrying out each of them.

The most influential indicator also on employees is discipline, according to the theory (McClelland, 2007) that the achievement characteristics of a manager/employee are being responsible for the work they carry out, having the ability to make decisions, and doing meaningful work and completing it with high discipline.

\section{RESEARCH METHODS}

The type of research used was a survey where the research was aimed at all populations in the research area. In terms of the analytical approach, this research was a descriptive type of research to systematically, factually, and accurately describe a particular population or area (Sugyono, 2017). The data in this study was quantitative. This data was needed to describe the research results. The collection of performance variable data with indicators of managerial ability, responsiveness, accountability, and work 
discipline is carried out directly on PNS at the Dikpora Kab. Mamuju.

The sampling technique used the census method in this research (Arikunto, 2010). survey research with the census research method is if all the population is sampled, so the number of samples in this study was 42 .

To obtain empirical data about the variables in this study, a questionnaire was used as an instrument that aims to collect information about the research variables. The conception that underlies the instrument's preparation departs from the indicators of the research variables described from the dimensions and theories used in explaining the variables of this study. Furthermore, it is poured into the instrument grid.

This questionnaire used a Likert scale which consisted of five kinds of choices. The tiered score for the answers to positive statements is 5,4,3,2,1, while for negative statements, a score was 1,2,3,4,5. Complete overview of the questionnaire grid.

\section{Instrument trial}

(Arikunto, 2010) explains that after the instrument is completed, the next step was to conduct a trial of the instrument. The purpose of the trial was to determine the instrument's validity and reliability as a requirement for an instrument that was suitable for use in a study. This research instrument was tested on 27 civil servants at the National Education Office of West Sulawesi Province who was taken randomly. The selection of civil servants at the Diknas of West Sulawesi Province to serve as a trial sample was based on the consideration that civil servants of the Office of National Education of West Sulawesi Province had almost the same functions and duties. With civil servants of the Dikpora Office of Mamuju Regency.

\section{Test the validity of the instrument}

Testing the instrument's validity is carried out to get an instrument that is suitable for use in a study and is reliable. (Priyatno, 2009) For this purpose, the researcher tested the instrument's validity using the validity and reliability scale functions and was based on the Pearson Product Moment correlation formula (Tiro, 2007).

Table 1. Summary of the results of the validity of the civil servant performance instrument

\begin{tabular}{llllll}
\hline Indicator & $\begin{array}{l}\text { Number } \\
\text { Questio } \\
\text { n Points }\end{array}$ & r-test & $\begin{array}{l}\text { r- } \\
\text { tabl } \\
\mathrm{e}\end{array}$ & Note \\
\hline Manager & $1,4,16$ & -.111, & - & .361 & Faile \\
Ability & & .004, & & $\mathrm{~d}$ \\
& 4,7 & .009 & .361 & \\
Responsive & & .0029, & .361 & Faile \\
Ability & 4,15 & .264 & .361 & $\mathrm{~d}$ \\
Accountabili & 3 & .275, & & Faile \\
ty & & .502 & & $\mathrm{~d}$ \\
Work & & -.254 & & Faiel \\
Discipline & & & & $\mathrm{d}$ \\
\hline
\end{tabular}

\section{Instrument reliability test}

The results of the instrument reliability test with the validity and reliability scale analysis functions are based on the Cronbach Alpha formula (Arikunto, 2010). Then the results of the instrument reliability analysis 
were as in Appendix 5, and these results indicate that the level of instrument reliability is very high. This can be described as follows: the reliability test of the PNS performance instrument in the first stage shows that the instrument reliability coefficient value of 0.948 is included in the very high category. Likewise, the reliability test in the second stage produces a reliability coefficient value of 0.966. This shows that the instrument that was used to measure the performance of PNS at the Dikpora Mamuju district has a very high level of consistency (reliability level) and can be relied on in actual research.

\section{Data collection technique}

1. Questionnaire

Data collection techniques with questionnaires were used to reveal respondents' responses to managerial abilities with 13 questions/statements, 7 items of responsiveness ability, 13 questions of accountability level, and 9 questions of work discipline level. The consideration of choosing a closed questionnaire model was none other than to make it easier for respondents to give scores, no need to write answers at length, and ease of coding.

\section{Observation}

Observation or observation is a daily human activity by using the five senses of the eye as the primary tool in addition to other senses such as ears, smell, mouth, and skin. Therefore, (Bungin, 2009) explains that observation is a person's ability to use his observations through the work of the five senses of the eye and assisted by other senses. With direct observation, it is hoped that it will further complete the questionnaire technique, which is thought to be difficult to question and strengthen and justify the data collected through the questionnaire technique. This observation can make it easier to explain the relationship of existing phenomena and help explain the results of the data from the questionnaire.

\section{Interview guide}

(Bungin, 2009) explains the interview technique (in-depth interview) is the process of obtaining information for research purposes using question and answer while face to face between the interviewer and the informant or the person being interviewed, with or without using an interview guide, in which the interviewer and informant are involved. In a relatively long social life. Interviews were conducted with civil servants at the Dikpora Kab. Mamuju, West Sulawesi. In this way, inputs can be obtained to deepen the study of the factors that affect the performance of civil servants. The interview guide was used to conduct interviews to be more focused and consistent in the data collection results.

In this interview the informants were: (1) Head of Service, (2) Head of Division 3 people, (3) Head of section 2 people, (4) Section head 2 people, and (5) staff 2 people. 


\section{Data analysis technique}

This study used two data analyses: (1) quantitative descriptive data analysis as the main analysis, and (2) qualitative descriptive data analysis as supporting analysis. Quantitative descriptive statistical analysis techniques were used to describe the variables in the study, namely the performance of civil servants at the Dikpora Service, that this descriptive statistical analysis technique was also used to describe each research indicator, such as (1) managerial ability level, (2) responsiveness level ability. Civil servants, (3) the level of accountability, and (4) the level of work discipline of civil servants.

For this purpose, calculated: (1) mean, (2) median, (3) mode, (4) standard deviation, and (5) a frequency table for which a histogram is then made. Before making the frequency distribution and histogram of employee performance variables and indicators, the stages of work carried out (Tiro, 2007) are: (1) determining the number of classes or data groups, (2) determining class boundaries, (3) entering data into appropriate class, and (4) calculate the number of data in each class. The following Sturges criteria were used to determine the number of interval classes.

$$
\begin{gathered}
\hline \mathrm{k}=1+3,33 \log \mathrm{n} \\
\text { Where: } \mathrm{k}=\text { number of classes formed } \\
\mathrm{n}=\text { number of observations or data then }
\end{gathered}
$$
calculate the class width (1):

$$
\mathrm{l}=\frac{\text { Highest Score }- \text { Lowest Score }}{\text { Amount of Class }}
$$

Qualitative descriptive data analysis using interview and observation instruments in collecting data. Qualitative descriptive data analysis was used to support the results of quantitative descriptive analysis, so that each description category was enriched and strengthened by qualitative data from interviews and observations. The results of this qualitative descriptive analysis also helped in providing conclusions for each problem that had been described by quantitative descriptive analysis.

\section{DISCUSSION}

\section{Managerial Ability}

The managerial ability score is 61 , and the minimum score obtained is 26 . Thus, it can be described in detail the acquisition scores for the administrative ability indicators in the form of a frequency distribution table as follows:

Table 2. Frequency distribution of civil servant managerial abilities

\begin{tabular}{llll}
\hline $\begin{array}{l}\text { Score } \\
\text { Interval }\end{array}$ & Category & Frequency & Percentage \\
\hline $13-30$ & Low & 2 & 4,76 \\
$31-48$ & Average & 24 & 57,14 \\
$49-66$ & High & 16 & 38,10 \\
\hline Total & & 42 & 100 \\
\hline
\end{tabular}

The managerial ability of Civil Servants of the Dikpora Service is included in the moderate category. This is also by the opinions of the following experts:

a. Managerial ability is competence or a leadership ability to carry out a job given to him as a responsibility or task based on skills and knowledge and supported by the 
work attitude required by the job, to produce a good job, use all the potential that is owned both external and internal. (Wibowo, 2009).

b. Managerial ability in an organization is an integrated taxonomy of leader behavior in building relationships. The built relationships will support work completion, develop and guide staff, build teams and manage conflict, and formwork networks between lines. Of particular concern to the achievement of performance by managers is making decisions which include planning, problem-solving, consulting, and delegating (Yulk, 2005).

In line with this opinion, the measurement of managerial ability with indicators: (1) the ability to influence, (2) the ability to encourage, (3) the ability to make decisions, and (4) communication skills at the Dikpora Office are not optimal, and there is a need for a program in managerial ability development. Every employee can improve managerial ability because it can be learned in knowledge.

The results of this study are reinforced by the results of research (Wirda \& Azra, 2015) that managerial competence affects business performance in organizations (industry). A high level of education, mature age, and a long working period make experienced managers more competent and professional in managing their business which in turn affects business performance

\section{Responsiveness Ability}

Based on the theoretical score, the highest is 35 , and the lowest is 7 . In detail, the distribution of the scores for the responsiveness of PNS at the Dikpora Service can be shown in the following frequency distribution table:

Table 3. Frequency distribution of the responsiveness of civil servants

\begin{tabular}{llll}
\hline $\begin{array}{l}\text { Score } \\
\text { Interval }\end{array}$ & Category & Frequency & Percentage \\
\hline $7-16$ & Low & 2 & 4,76 \\
$17-26$ & Average & 25 & 59,53 \\
$27-36$ & High & 15 & 35,71 \\
\hline Total & & 42 & 100 \\
\hline
\end{tabular}

The responsiveness ability of Civil Servants of the Dikpora Service is included in the medium category. This is also by the results of interviews with the Head of Dikmen, according to the opinions of the following experts:

a. Responsiveness is a concept related to public administrators' professional standards and technical competencies to carry out their duties. Public organizations are said to be responsive if the perpetrators have high standards of professionalism or competence to assess public organizations' attitudes, behavior, and policies must have administrative standards (Nasucha, 2004).

b. Subjective responsiveness prioritizes ethical and human values, which are summarized as inequality and fairness to provide services to the community and other administrative tasks (Islami, 1986). 
These two opinions are in line with the measurements taken to determine the level of responsiveness with indicators: (1) The relationship between program activities and needs, (2) The responsiveness of the apparatus in dealing with and resolving complaints submitted by the community, and (3) Availability of opportunities and a forum for the community to convey suggestions and needs. Assessment of responsiveness ability is closely related to human values and ethical values in providing services to the community.

The results of this study are in line (Triyanto 2017) that to measure performance using five performance dimensions, namely productivity, responsiveness, responsibility, accountability and service quality and performance barriers, namely personal, leadership, team, system, and contextual factors.

\section{Accountability of Civil Cervant at the Dikpora Service}

The maximum score for accountability data is 65 , and the lowest is 13 . The managerial ability of civil servants can be described in the form of a frequency distribution table as follows:

Table 4. Distribution of the frequency of accountability of Civil Servants

\begin{tabular}{llll}
\hline $\begin{array}{l}\text { Score } \\
\text { Interval }\end{array}$ & Category & Frequency & Percentage \\
\hline $13-30$ & Low & 1 & 2,38 \\
$31-48$ & Average & 12 & 28,57 \\
$49-66$ & High & 29 & 69,05 \\
\hline Total & & 42 & 100 \\
\hline
\end{tabular}

Accountability of Civil Servants of the Dikpora Service is included in the high category. It is by the results of interviews with the Head of Youth and Sports, and according to the opinions of experts as follows:

a. Accountability is the implementation of the responsibility of a person or a public organization that the authorities can hold accountable (Yuwono Teguh, 2003).

b. There are four dimensions of public accountability, namely: (1) honesty and legal accountability, (2) program accountability, (3) policy accountability, and (4) process accountability (Veithzal Rivai, 2005).

The above opinion is also by the indicators that measure the accountability of civil servants, namely: (1) carrying out tasks according to their duties, (2) utilizing office facilities, (3) establishing working relationships with office colleagues, and (4) loyalty to the leadership. The high accountability of civil servants leads to maximum performance management so that the achievement of the organization's vision and mission can be realized.

\section{Civil servant work discipline}

The highest theoretical score is 45 , and the lowest score is 9. In detail, the distribution of work discipline gains for PNS at the Dikpora Service can be shown in the following frequency distribution table: 
Table 5. Frequency distribution of civil servant work discipline

\begin{tabular}{llll}
\hline $\begin{array}{c}\text { Score } \\
\text { Interval }\end{array}$ & $\begin{array}{c}\text { Categor } \\
\text { y }\end{array}$ & $\begin{array}{c}\text { Frequenc } \\
\text { y }\end{array}$ & $\begin{array}{c}\text { Percent } \\
\text { age }\end{array}$ \\
\hline $9-21$ & Low & 3 & 7,14 \\
$22-34$ & Average & 28 & 66,67 \\
$35-47$ & High & 11 & 26,19 \\
\hline Total & & 42 & 100 \\
\hline
\end{tabular}

The work discipline of Civil Servants of the Dikpora Service is included in the medium category. It is by the results of interviews with the Head of the Personnel Division and according to the opinions of the following experts:

a. Discipline is the essential operative function of human resource management because the better the work discipline, the higher the work performance that can be achieved. Without Discipline, it is difficult for an organization to achieve optimal results (Hasibuan, 2007). So in principle, the Discipline of an employee can be interpreted as his awareness and willingness to obey the rules and norms that apply in the workplace.

b. Steady Discipline will essentially grow and radiate from human consciousness results. Discipline that does not originate from human conscience will result in weak Discipline and not last long (Sedarmayanti, 2008). Work discipline does not last and will quickly fade. Discipline that grows based on self-awareness is expected to be permanently embedded in every employee.

Starting from the two opinions, it can be concluded that civil servant discipline is needed to improve performance achievement. Therefore, the Discipline of civil servants needs to be considered in providing rewards and punishments that can generate efforts to achieve organizational goals.

The results of this study are in line with the results of research (Ferawati, 2017) that work Discipline and work environment positively influence employee performance.

Overview of the performance of the Dikpora Service Civil Servants

From the analysis, the maximum Civil Servant performance data expected in this study based on the highest score is 210 , and the lowest is 42 . This is following the number of questions to measure PNS performance indicators as many as 42 . The results show that the maximum score obtained is 183 , and the minimum score is 183 . The obtained score is 90. Thus, the acquisition score can be described in detail in the form of a frequency distribution table as follows:

Table 6. Frequency distribution of Civil Cervant performance

\begin{tabular}{llll}
\hline Interval skor & Kategori & $\begin{array}{l}\text { Frekuen } \\
\text { si }\end{array}$ & Persentase \\
\hline $42-97$ & Rendah & 1 & 2,38 \\
$98-153$ & Sedang & 23 & 54,76 \\
$154-210$ & Tinggi & 18 & 42,86 \\
\hline Jumlah & & 42 & 100 \\
\hline
\end{tabular}

The performance of Civil Servants at the Dikpora Office is included in the medium category. It is by the results of interviews with the Head of the Personnel Division and 
according to the opinions of the following experts:

a. Managerial ability is a competency or an ability to carry out a job given to him as a responsibility or task based on skills and knowledge and supported by the work attitude required by the job, to produce a good job, use all the potential possessed both externally. And internally (Wibowo, 2009).

b. Responsiveness is a concept related to public administrators' professional standards and technical competencies to carry out their duties (Nasucha, 2004). Public organizations are said to be responsive if the perpetrators have high standards of professionalism or competence to assess public organizations' subjective attitudes, behavior, and policies.

c. Accountability is an employee's responsibility in carrying out any work that has been entrusted to him. If someone can carry out his duties and responsibilities well, he will show better performance as well (Nawawi, 2006).

d. Discipline is the most important operative function of human resource management because the better the work discipline (Davis, Keith, and John, 2005), the higher the work performance that can be achieved. Without discipline, it is difficult for an organization to achieve optimal results. So in principle, the discipline of an employee can be interpreted as his awareness and willingness to obey the rules and norms that apply in the workplace.

The results of this study were strengthened (supported) by the results of interviews with the Head of the Personnel Section, which stated that:

"Performance achievement depends on the placement of an employee whether it is an echelon official or staff, the placement of employees recommended by the BAPERJAKA team should be based on the results of the fit and professional test or based on the results of an employee's performance evaluation, so that the competencies possessed by employees are in accordance with the tasks which will be done on a daily basis. However, the current condition of the placement of an official and staff tends to be due to temporary political interests. So it can happen that there are employees who have the potential but cannot develop because of the placement factor.".

a. the characteristics of each employee are skills, education, experience, sincerity, and motivation. (Hasibuan, 2007) If you look closely, the performance is a behavior created by individuals carrying out the tasks or workload given.

b. Work experience is determined from a person's tenure when occupying a particular position or profession. The reality that occurs in the field shows that the level of education possessed by a person is not a guarantee that he will work professionally. 
Therefore, it takes the ability to understand and recognize the work environment that is practiced (H Handoko, 2000). The performance standards are set following what was stated (Dwiyanto, 2002) that to measure the performance of public services bureaucracy can be done in terms of (1) the concept of productivity, productivity measures not only the level of efficiency but also service effectiveness. Productivity is generally understood as the ratio between input and output, (2) service quality, the issue of service quality tends to be increasingly important in explaining the performance of public service organizations. Many negative views formed regarding public organizations arise because of general dissatisfaction with the quality of services received from public organizations,

(3) responsiveness, responsiveness is the organization's ability to recognize community needs, develop service agendas and priorities and develop public service programs according to requirements. And aspirations of the community, responsibility explains whether the implementation of the activities of this public organization is carried out by correct administrative principles or by organizational policies, both explicit and implicit, (5) accountability, public accountability shows how much policy and The activities of public organizations are subject to political officials elected by the people. The assumption is that these political officials are selected because the people elect them. They will always represent the people's interests, (6) service orientation shows how much energy public organizations use in providing public services.

The description of the performance shown by all civil servants of the Dikpora Office of Mamuju Regency can be categorized as moderate. This is due to:

a. The acceleration of the development of Mamuju Regency as the provincial capital is not balanced with the acceleration of increasing human resources (HR) at the Dikpora Office.

b. The range of employee mutations is not based on a needs assessment but at the regional election democracy party.

c. The promotion of civil servants is not based on a job analysis and job analysis or the fit and prover tests.

d. The lack of office facilities and infrastructure.

The performance of PNS at the Dikpora Office is in the medium category or other words, PNS at the Dikpora Office is more responsible for improving their interpretation by the existing work standards in each Field and Section at the Dikpora Office, Mamuju Regency. The difference in the level of performance that occurs in PNS at the Dikpora Office of Mamuju Regency is a natural 
phenomenon. This is mainly due to the heterogeneity of PNS at the Dikpora Office, both in terms of:

a. Level of work experience.

b. Level of education.

c. Skills of each employee.

d. Work culture.

This is in accordance with the opinion (Hasibuan, 2007) which says that differences in these characteristics such as experience, skills, education, sincerity, and motivation are characteristics that everyone owns, and this can affect a person's level of performance, especially employees in the Office of the Republic of Indonesia. Dikpora Mamuju Regency..

The performance shown by PNS of the Dikpora Service in carrying out daily tasks is not by what was stated by (Sianipar, 1999) which says that there are several dimensions of characteristics or attributes that must be considered in providing services, namely: (1) certainty of service time, (2) service accuracy, (3) responsibility, (4) completeness, (5) politeness and friendliness in providing services, (6) ease of obtaining services, (7) various service models, (8) service support attributes, ( 9) personal service, and (10) convenience in obtaining service. Some of the characteristics stated above should concern every civil servant of the Dikpora Office of Mamuju Regency, especially in providing services to the community or education stakeholders.
The study results are also strengthened by (Hidayati \& Syamyudi, 2017) that by meeting the service standards of the employee, the organization he runs can also achieve good performance. Good organizational performance is expected to provide satisfaction to consumers in their services. Employee performance that supports organizational performance is expected to meet consumer satisfaction, which can be measured: 1) reliability, 2) responsiveness, 3) assurance, and 4) empathy.

Other Factors Affecting the Performance of Civil Servants at the Dikpora Office of Mamuju Regency Based on the results of research that has been carried out previously, namely through interviews and observations, it shows that the performance of civil servants at the Dikpora Office is strongly influenced by several factors, namely: (1) work experience factors, (2) skills factors, (3) education factors, and (4) factors work culture. The results of this study strengthen research (Rosmaini \& Tanjung, 2019) that better employee performance needs to be increased competence through training for employees according to their field of work, having work experience, expertise, knowledge, skills, and educational background that supports the profession. For employees, so that work results can be maximized.

The results of this study are supported by the Kebid Dikmen explanation that: 
"They register to become employees not to serve and serve, but to seek status and salary, so of course when they work, their orientation is not by their main duties and functions as civil servants and the current condition is regional autonomy, where regions have the authority to Regulating regions in the context of accelerating development for the welfare of the community, but on the other hand in terms of career development, it is very dependent on who is supported in the election of regents".

To continuously improve their performance, all PNS of the Dikpora Office need to pay attention to in establishing reliable teamwork in providing services to the community. According to (Gibson, James L., 1996) that the factors that influence the performance are: (1) individual aspects, (2) organizational aspects, (3) psychological aspects that civil servants can unite. In addition, based on the observations of researchers that all civil servants of the Dikora Service must have the characteristics as stated by (Wibowo, 2009) that the aspects of people who have good performance are: (1) having self-confidence, (2) if work has an orientation for achievement, (3) can exercise self-control, (4) can carry out the tasks given, and (5) has a strong motivation to try to achieve better results or goals than the previous situation.

\section{CONCLUSION}

Analysis of the performance of civil servants at the Dikpora Office of Mamuju Regency can be concluded as follows:

1. The performance of civil servants at the Dikpora Office of Mamuju Regency as seen from (a) managerial ability, (b) responsiveness, (c) accountability, and (d) civil servant work discipline is not maximized or moderate category with a percentage of 54,76 .

2. Other factors that affect the performance of civil servants at the Dikpora Office of Mamuju Regency: (a) the supporting factors are work experience, skills, and education levels. And (b) the inhibiting factor is the work culture of civil servants

\section{REFERENCES}

[1] Arikunto, S. (2010). Manajemen Penelitian. Jakarta: Rineka Cipta.

[2] Agustang, A., \& Sahabuddin, J. (2020, October). Model kolaborasi sosial pendidikan karakter di sekolah swasta kecamatan bissappu kabupaten bantaeng. In prosiding seminar dan diskusi pendidikan dasar.

[3] Agustang, A., Suardi, S., Putra, A. D. M., \& Oruh, S. (2021). Pemberdayaan Guru Mata Pelajaran Sosiologi Melalui Literasi Digital Berbasis Quick Response Code di Kecamatan Bissappu Kabupaten Bantaeng. Abdi: Jurnal Pengabdian dan Pemberdayaan Masyarakat, 3(2), 175-188.

[4] Bungin, B. (2009). Penelitian Kualitatif; Komunikasi, Ekonomi, Kebijakan Publik, dan Ilmu social. Jakarta, Kencana Prenada Media group.

[5] Davis, Keith dan John, W. N. (2005). Prilaku dalam Organisasi. Penerjemah Agus Dharma. Jakarta: Erlangga. 
[6] Dwiyanto, A. (2002). Penilaian Kinerja Organisasi Publik. Yogjakarta: Fisipol UGM.

[7] Ferawati, A. (2017). Pengaruh Lingkungan Kerja Dan Disiplin Kerja Terhadap Kinerja Karyawan Pt. Cahaya Indo Persada. Jurnal Agora, 5(1), 1-131. http://eprints.uny.ac.id/41801/1/AdityaNurPr atama_12808144059.pdf

[8] Gibson, James L., J. M. I. dan J. H. D. J. (1996). Organisasi: Perilaku, Struktur, Proses. (Terjemahan) Edisi Delapan. Jakarta: Binarupa Aksara.

[9] H Handoko. (2000). Manajemen Personalia Dan Sumber Daya Manusia,. Yogyakarta: BPFE Yogyakarta.

[10] Hasibuan. (2007). Manajemen Sumber Daya Manusia. Jakarta: Bumi Aksara.

[11] Hidayati, S. N., \& Syamyudi, S. (2017). Analisis Kinerja Pegawai guna Menunjang Kinerja Organisasi dalam Memberikan Pelayanan Masyarakat. Jurnal Maksipreneur: Manajemen, Koperasi, Dan $\begin{array}{lll}\text { Entrepreneurship, } & 6(2), & 65 .\end{array}$ https://doi.org/10.30588/jmp.v6i2.303

[12] Islami, I. (1986). Agenda Reformasi Administrasi Negara.Pidato Pengukuhan Guru Besar Ilmu Kebijakan Publik pada Fakultas Ilmu Administrasi. Malang: UNBRAW.

[13] Masinambow, C., \& Adolfina. (2017). Analisis Perbandigan Kinerja Pegawai PNS dan Non PNS di Politeknik Negeri Manado. Jurnal EMBA, 5(2), 1093-1101.

[14] McClelland, D. (2007). David c. mcclelland's motivational needs theory. http://www.busunessballs.com/davidmcclell and.htm

[15] Nasucha, C. (2004). Reformasi Administrasi Publik. Jakarta: PT Grasindo.

[16] Nawawi, H. (2006). Kepemimpinan Mengefektifkan Organisasi. yogyakarta: Gajah Mada University Press.

[17] Priyatno, D. (2009). 5 Jam Belajar Olah data dengan SPSS 17. Yogyakarta: CV. Andi Offset.
[18] Retno Sulistiyo. (2019). Anslisis Kinerhja Pegawai Negeri Sipil (PNS) Pada Sub. Bagian Umum Dan Kepegawaian Kantor BAPPEDA Provinsi Kalimantan Timur. Ejurnal.Untag-Smd.Ac.Id.

[19] Robins, P. S. T. H. P. (2001). Perilaku Organisasi. Konsep, Kontraversi, Aplikasi. Edisi Kedelapan Versi Bahasa Indonesia. Jilid I. Jakarta: Prenhallindo.

[20] Rosmaini, R., \& Tanjung, H. (2019). Pengaruh Kompetensi, Motivasi Dan Kepuasan Kerja Terhadap Kinerja Pegawai. Maneggio: Jurnal Ilmiah Magister Manajemen, 2(1), 1-15. https://doi.org/10.30596/maneggio.v2i1.336 6

[21] Sedarmayanti. (2008). Manajemen Sumber Daya Manusia. Bandung: PT Refika Aditama.

[22] Sianipar, J. P. G. (1999). Manajemen Pelayanan Publik. Bahan Diklat Prajabatan Golongan III. Jakarta: Lembaga Administrasi Negara Republik Indonesia.

[23] Sugyono. (2017). Metode Penelitian Kuantitatif, Kualitatif dan $R \& D$. Bandung: Alfabeta.

[24] Suardi, S., Agustang, A., \& Jumadi, J. (2021). Dominasi Sekolah Negeri Terhadap Sekolah Swasta Sebagai Penyebab Kekerasan Simbolik Terhadap Siswa Sekolah Swasta. Jurnal Ilmiah Muqoddimah: Jurnal Ilmu Sosial, Politik dan Hummanioramaniora, 5(2).

[25] Terry, G. R. (2008). Prinsip-Prinsip Manajemen. Jakarta: Bumi Aksara.

[26] Tiro, M. A. (2007). Statistika Terapan untuk Ilmu ekonomi dan Ilmu Sosial. Makassar: Andira Publisher.

[27] Triyanto, D. (2017). Analisis Kinerja Organisasi dalam Mewujudkan Pelayanan Prima kepada Masyarakat (Studi Pada Kantor Badan Pelayanan Perizinan Terpadu Kota Semarang). Mimbar Jurnal Penelitian Sosial Dan Politik, 6(4), 6-13.

[28] Veithzal Rivai. (2005). Performance Appraisal. Jakarta: PT Raja Grafindo Persada. 
[29] Wibowo. (2009). Manajemen Kinerja. Jakarta: Raja Grafindo Persada.

[30] Wirda, F., \& Azra, T. (2015). Kompetensi Manajerial Dan Pengaruhnya Terhadap Kinerja Industri Kreatif Sumatera Barat. Proceeding, http://fe.unp.ac.id/sites/default/files/unggaha n/6. Fisda Wirda\%2C Tuti Azra \%28hal 183192\%29_0.pdf

[31] Yulk, G. (2005). Kepemimpinan dalam Organisasi. Jakarta: PT Indeks.

[32] Yuwono Teguh. (2003). Manajemen otonomi Daerah, Membangun Daerah Berdasarkan Paradigma Baru. Semarang: CLOGAPPS.

[33] Undang-Undang Nomor 23 Tahun 2014 tentang Pemerintahan Daerah

[34] Undang-Undang Nomor 20 Tahun 2003 tentang Sistem Pendidikan Nasional 